\title{
Development of Energy and Environment Education Program and Teaching Aids for Upper Grade of Elementary School by Effective Utilization of Regional Collaboration
}

\author{
Koichi Takaki Member (Iwate University) \\ Nobuo Jinno Non-member (Iwate University) \\ Shogo Kajiwara Non-member (Iwate University) \\ Akira Yamaguchi Non-member (Iwate University) \\ Masahiko Kikuchi Non-member (Yahaba-higashi Elementary School) \\ Momoko Suzuki Non-member (Yahaba-higashi Elementary School)
}

Keyword : ESD, sustainable development, synthetic learning, energy, environment, experience learning

Energy and environment education learning unit for upper grade of elementary school was developed and carried out. A regional collaboration among elementary schools, universities and municipal governments was utilized to develop the learning unit effectively. The learning unit was proposed based on the analysis using questionnaires done to the sixth grade students in Yahaba-Higashi elementary school.

The results of the analysis revel that the $78 \%$ students acquire the knowledge about energy and environment by the previous times of synthetic learning. However, the students do not have strong motivation to act for remediation of the energy and environmental circumstances, whereas they have rich-knowledge about those issues.

Based on the analysis, the learning unit of energy and environment was designed with focusing to get the skill through the demonstrational experiment developed and/or arranged by academic staffs in Iwate University and in Yahaba-Higashi elementary school. The designed learning unit consists two courses; one is electricity production learning and the other is fuel cell learning. The detail of two courses is shown in Table 1.

The designed learning program was carried out as time of synthetic learning for sixth grade students in Yahaba-Higashi elementary school and was evaluated by questionnaires. The results showed the designed energy and environment learning program motivated to act locally for sustainable development as shown in Fig. 1.
Table 1. Contents of the learning unit

\begin{tabular}{|c|c|c|c|}
\hline Curses & No. & Contents & teaching materials \\
\hline \multirow{4}{*}{$\begin{array}{l}\text { Curse A; } \\
\text { Electricity } \\
\text { production }\end{array}$} & $A-1$ & $\begin{array}{l}\text { Amazing materials for } \\
\text { electricity generation }\end{array}$ & $\begin{array}{l}\text { Lemon, solar cell, } \\
\text { wind power, thermal- } \\
\text { energy conversion }\end{array}$ \\
\hline & $A-2$ & \begin{tabular}{|l|} 
Let's try electricity \\
generation!
\end{tabular} & \begin{tabular}{|l|} 
Bicycle power \\
generator
\end{tabular} \\
\hline & $A-3$ & $\begin{array}{l}\text { Mechanism in power } \\
\text { plant }\end{array}$ & $\begin{array}{l}\text { Thermal power plant } \\
\text { model }\end{array}$ \\
\hline & $A-4$ & $\begin{array}{l}\text { Magnet and electricity } \\
\text { generation }\end{array}$ & AC generator model \\
\hline \multirow{4}{*}{$\begin{array}{l}\text { Curse B; } \\
\text { Fuel cell }\end{array}$} & B-1 & $\begin{array}{l}\text { Let's try hydrogen } \\
\text { production! }\end{array}$ & $\begin{array}{l}\text { Instrument of water } \\
\text { electrolysis }\end{array}$ \\
\hline & B-2 & $\begin{array}{l}\text { Let's try to run a car } \\
\text { using hydrogen! }\end{array}$ & One cell car \\
\hline & B-3 & $\begin{array}{l}\text { Large power generation } \\
\text { by stacked fuel cell }\end{array}$ & Stacked fuel cell \\
\hline & B-4 & Let's make a fuel cell & $\begin{array}{l}\text { Handcraft set of fuel } \\
\text { cell }\end{array}$ \\
\hline
\end{tabular}

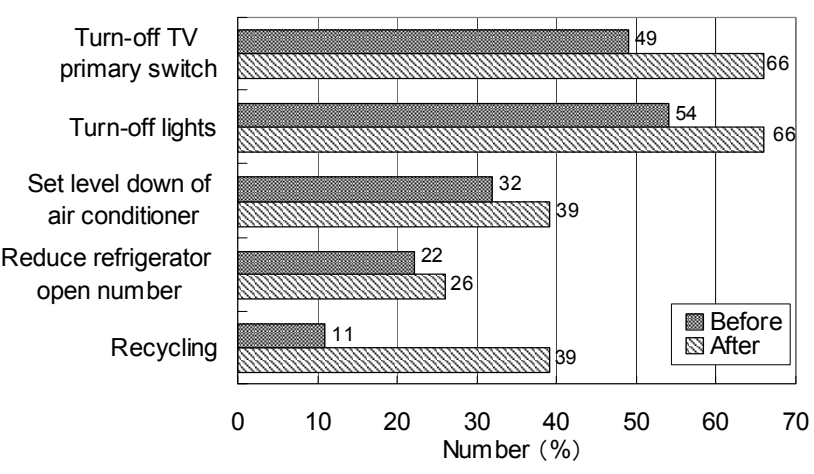

Fig. 1. Comparison on activity for environmental action between before and after the course for energy education 


\section{地域連携を活用した小学校高学年用エネルギー環境 学習プログラムと教材の開発}

\begin{tabular}{|c|c|c|c|c|}
\hline 正 員 & 高木 & 浩一* & 非会員 & 甚野 \\
\hline 非会員 & 梶原 & 昌五* & 非会員 & 山口 \\
\hline & & 雅彦** & 非会員 & \\
\hline
\end{tabular}

\section{Development of Energy and Environment Education Program and Teaching Aids for Upper Grade of Elementary School by Effective Utilization of Regional Collaboration \\ Koichi Takaki*, Member, Nobuo Jinno*, Non-member, Shogo Kajiwara*, Non-member, Akira Yamaguchi*, Non-member, \\ Masahiko Kikuchi**, Non-member, Momoko Suzuki**, Non-member}

Development of energy and environment education learning unit for upper grade of elementary school is described in this paper. A regional collaboration among elementary schools, universities and municipal governments was utilized to develop the learning unit effectively. The learning unit was proposed based on the analysis using questionnaires done to the sixth grade students in Yahaba-Higashi elementary school. The results of the analysis revel that the $78 \%$ students acquire the knowledge about energy and environment by the previous times of synthetic learning. However, the students do not have strong motivation to act for remediation of the energy and environmental circumstances, whereas they have rich-knowledge about those issues. Based on the analysis, the learning unit of energy and environment was designed with focusing to get the skill through the demonstrational experiment developed and/or arranged by academic staffs in Iwate University and in Yahaba-Higashi elementary school. The designed learning program was carried out as time of synthetic learning and was evaluated by questionnaires. The results showed the designed energy and environment learning program motivated to act locally for sustainable development.

キーワード : ESD, 持続可能な開発, 総合的な学習, エネルギー, 環境, 体験学習

Keywords : ESD, sustainable development, synthetic learning, energy, environment, experience learning

\section{1. はじめに}

2005 年から「ESD (Education for Sustainable Development) の 10 年」が始まった ${ }^{(1)}$ 。これは持続可能な開発のための教 育の意味で，1992 年 6 月の，国連環境開発会議（地球サミ ット）の国際的行動指針「アジェンダ $21 」 や ，$ 持続可能な 開発に関する世界首脳会議（ヨハネスブルグサミット）で 日本が提言した「ESDの 10 年」を受けての実施になる。 「ESD の 10 年」で重要視されている 3 つの分野は, 社会・ 環境・経済であり，これらの分野に力点を置いた教育プロ グラムの開発・実施が進められている。具体的には，環境

\footnotetext{
* 岩手大学

干 020-8551 盛岡市上田 4-3-5

Iwate University

4-3-5, Ueda, Morioka 020-8551

** 矢巾東小学校

产028-3602 岩手県紫波郡矢巾町藤沢 2-11

Yahaba-higashi Elementary School

2-11, Fujisawa, Yahaba, Shiwa, Iwate 028-3602
}

教育, 多文化共生教育, 福祉教育, 人権教育, 平和教育, ジェンダー教育などがあげられる。これらの教育は, 人材 の面から, 各教育機関単独で行うのは難しく, 地域連携な どを効果的に使った教育が必要となる。特に初等教育機関 では, 行政機関, NPO 団体, 大学など研究機関の連携で進 める例が多い。

「持続可能な社会」を考えた場合，これまでにも増して重 要になるのがエネルギー教育である。これまで，初等教育 機関において, エネルギー教育を理科教育, 環境教育の中

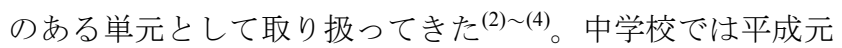
年の新指導要領で「エネルギー資源」を，「地球と人間」か ら「科学技術と人間」の中で学ばせるなどの工夫が施され た。また高等学校でも 2003 年の新課程で, 理科基礎, 理科 総合 $\mathrm{A}$, 理科総合 $\mathrm{B}$ に「エネルギー」の科学的な考え方の 単元が位置づけられるなど, エネルギー教育の比重は増え ている。しかし，小学校では，B 領域を「物質とエネルギー」 分野と位置づけてはいるが，児童のエネルギー概念の形成 


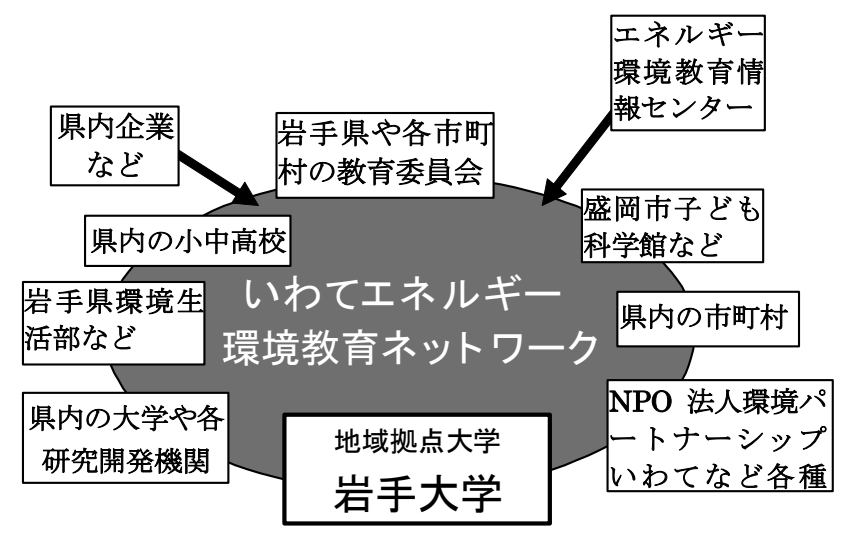

図 1 いわてエネルギー環境ネットワークの組織図

Fig. 1. Schematic diagram of Iwate Network for Energy and Environment Education.

は十分に行われていない(5)。小学校の児童に限らず，「エネ ルギー」の概念は複雑で，日本では「パワー」の概念と， 科学的な「エネルギー」の概念が混在しているのが実状で ある(5)。このような状況から，小学校の「エネルギー」教育 用の体験学習に基づくプログラムの策定や，それに伴う教 材の開発が急務となる。このためには, 幅広い分野の研究 機関や教育機関，行政機関，企業が協力して対応する必要 がある。

岩手大学では, 現在, 地域のエネルギー環境教育をサポ 一トする活動を進めている。活動の母体として,「いわてエ ネルギー環境教育ネットワーク（INEEE; Iwate Network for Energy and Environment Education) 」( ${ }^{(6)}$, 図 1 に示すように, 学内の学部横断的に集まった先生を中心に, 小中高校の先 生, 盛岡市子ども科学館, 教育委員会, 行政機関, 他県の エネルギー環境教育関係者で構成し，体験学習等を企画・ 実施している。活動を大きく分けると，（1）イベントを通 した啓蒙活動，（2）講演会・研修会を通した勉強会の実施, （3）学校の教育プログラムの策定，（4）前項を実施する ための教材開発になる。

本論文では, 地域のエネルギー環境教育をサポート活動 の一環として取り組んだ，小学校高学年へのエネルギー教 育の設計と, 教材開発について述べる。学習の実施には, 総合的な学習の時間を利用した。授業は，（1）アンケート 調查などをべースにした児童の実態に即した計画立案， （2）理科・科学・工作教室などのイベントを通した教材開 発，（3）総合的な学習の実施の手順で行い，実施後の評価 にはアンケートや感想文などを用いた。

\section{2. 地域における理科教室を利用した準備}

総合的な学習の時間で使用する教材開発などを目的に, いくつかの理科教室などのイベントを主催もしくは共催し た。表 1 に, 小学校での総合的な学習実施前に行ったイ心゙ ントの名称と参加人数など示す。いわてエネルギー環境教 育ネットワークは 2005 年 8 月 3 日に組織された。従って, 活動は 8 月からとなる。イベントは講演会, 工作や体験学
表 1 INEEE 関係のイベントとその参加人数 Table 1. List of invents held by INEEE.

\begin{tabular}{|c|c|c|c|c|c|}
\hline $\begin{array}{c}\text { 実施日 } \\
\text { (平成17年) }\end{array}$ & イベント名称 & 会場 & 実施 & $\begin{array}{l}\text { 参加対 } \\
\text { 象 }\end{array}$ & 参加人数 \\
\hline $\begin{array}{c}\text { 8月6日 } \\
\text { 〜7日 }\end{array}$ & $\begin{array}{l}\text { サイエンスパートナーシップ; 物 } \\
\text { 理実験 }\end{array}$ & 岩手大学 & 共催 & 高校生 & 21人 \\
\hline $\begin{array}{c}\text { 8月20日 } \\
\sim 21 \text { 日 } \\
\end{array}$ & イーハトーブの科学と技術展 & $\begin{array}{l}\text { 滝沢村イオンショッ } \\
\text { ピングセンター }\end{array}$ & $\begin{array}{l}\text { 共同 } \\
\text { 主催 } \\
\end{array}$ & 一般 & 2010人 \\
\hline 8月27日 & INS夏季講演会 & 岩手大学 & $\begin{array}{l}\text { 共同 } \\
\text { 主催 } \\
\end{array}$ & 一般 & 約 $140 人$ \\
\hline 9月6日 & ミニエネルギー展 & 矢巾東小学校 & 主催 & $\begin{array}{l}\text { 小学生 } \\
\text { と父母 }\end{array}$ & 約60人 \\
\hline 10月2日 & $\begin{array}{l}\text { 驚きのスーパーサイエンス } \\
\text { ショョー }\end{array}$ & 水沢南公民館 & \begin{tabular}{|l|l|l|l|} 
共同 \\
主催
\end{tabular} & 一般 & 250 人 \\
\hline $\begin{aligned} \text { 10月14日 } \\
\sim 15 \text { 日 } \\
\end{aligned}$ & ESD-J地域ミーティングin岩手 & 岩手大学 & 後援 & 一般 & 約40人 \\
\hline $\begin{array}{r}\text { 10月21日 } \\
\sim 22 \text { 日 } \\
\end{array}$ & $\begin{array}{l}\text { サイエンスパートナーシップ; 化 } \\
\text { 学教員研修 }\end{array}$ & 岩手大学 & 共催 & $\begin{array}{l}\text { 高校 } \\
\text { 教師 }\end{array}$ & 約20人 \\
\hline 10月22日 & $\begin{array}{l}\text { 前沢商エまつり; エネルギー環 } \\
\text { 境コーナー }\end{array}$ & $\begin{array}{c}\text { 前沢ふれあい } \\
\text { センター }\end{array}$ & 共催 & 一般 & 約40人 \\
\hline
\end{tabular}

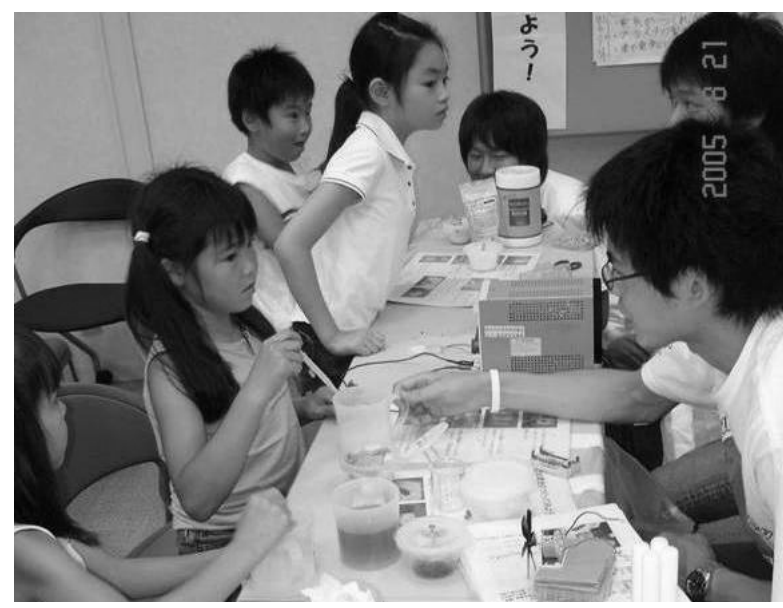

図 2 燃料電池の工作の様子

Fig. 2. Photograph of a handicraft class for fuel cell.

習などの理科教室である。上記のうち, 小学生が主な参加 者となった体験型学習教室は, 「イーハトーブの科学と技 術展」,「ミニエネルギー展」,「驚きのスーパーサイエンス ショー」の3つである。

イベントの一例として, イーハトーブの科学と技術展（岩 手大学, 地域連携推進センター, Iwate Network System; INS などの団体との共同開催) での様子を図 2 に示す。ここで は,「太陽の恵み」をテーマとして, 生態系や新エネルギー 関係の工作やデモ, 教材紹介などを行った。図 2 は, 燃料 (炭) 電池の工作の様子である。イベントでは, 図 3 に示す ような，工作マニュアルを作成した。材料も， 1 円ショップ などで入手可能なもの, 総費用も, 小学校への教材として 導入できるように 100 円程度になるように工夫した。例え ば, 図 3 に示す工作には, 小型のタッパー, 入浴剤, ねじ くぎ, キッチンタオル, 消臭用活性炭を利用している。

表 2 に, 表 1 のイベントで用いた教材リストを示す。こ れらは小中学校や高等学校のエネルギー教育の教材を意識 して揃えたものである。これらは, 表 1 に示すようなイべ ントで，エネルギー環境関連の説明や体験学習で使用し， その反応を見ながら, 学校現場に教材として利用する場合, どのような単元で，どのように利用するのが最適なのかを 検討する材料とした。

その他の特記事項として，イベントには 1〜2 人のスタッ 
フ以外に，学生で組織しているエネルギー環境ボランティ アから，4〜6 人参加して，学生中心に実施した。現在の大 学生のエネルギー環境に対する知識や意識は, 決して十分 高いとはいえない(7)。学生中心にイベントを行うと, 学生の エネルギー環境に対する意識も高まることが期待でき，岩 手大学が現代 $\mathrm{GP}^{(8)}$ の中で進めている,「環境教育と結び, 各 学部の特性を生かす全学知的財産教育」の方向性とも一致 する(9)。加えて, 多くの子供たちを相手にすることで, 学生 のレスポンス能力が高まる。これは，工学教育において特 に重要となる問題解決能力と深く関わる項目となる。
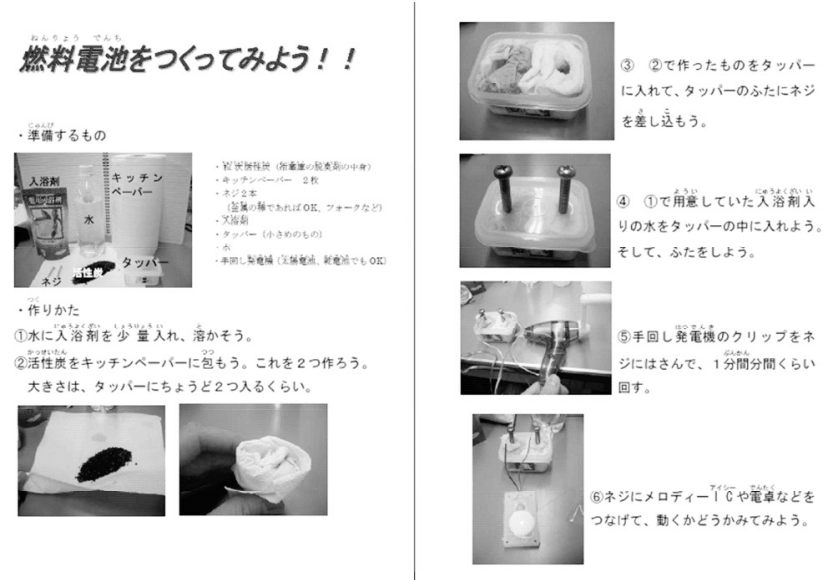

図 3 燃料電池工作のマニュアル

Fig. 3. Manual of a handicraft class for fuel cell.

表 2 イベントで用いた教材のリスト

Table 2. List of teaching materials for science class.

\begin{tabular}{|c|c|c|}
\hline 分類 & 分類No & 物品名 \\
\hline \multirow{3}{*}{ 1.燃料電池 } & $1-1$ & |燃料電池システム \\
\hline & $1-2$ & 燃料電池実験器 \\
\hline & $1-3$ & ワンセルカー \\
\hline \multirow{2}{*}{ 2.省エネ } & $2-1$ & 白熱電球·省エネ電球比較実験器 \\
\hline & $2-2$ & 蛍光灯·白熱電球エネルギー比較実験器 \\
\hline \multirow{8}{*}{ 3.新エネルギー } & $3-1$ & 風力発電機 \\
\hline & $3-2$ & ソーラーカー \\
\hline & 3-3 & 強カライト \\
\hline & $3-4$ & 花力発電(色素増感型太陽電池) \\
\hline & $3-5$ & ソーラークッカー \\
\hline & $3-6$ & 太陽電池 (大型) \\
\hline & $3-7$ & 太陽電池 (中型) \\
\hline & $3-8$ & 太陽電池(小型) \\
\hline \multirow{8}{*}{ 4. 発電 } & $4-1$ & 電磁誘導発電機 \\
\hline & $4-2$ & 火力発電実験器 \\
\hline & $4-3$ & ハンドパワージュネレーター \\
\hline & 4-4 & ナイトスター \\
\hline & $4-5$ & 電池実験セット(3種類) \\
\hline & $4-6$ & 11円電池 \\
\hline & $4-7$ & 温度差発電機 \\
\hline & $4-8$ & ゼネコン \\
\hline \multirow{3}{*}{ 5. 高電圧 } & $5-1$ & テスラコイル \\
\hline & 5-2 & ルーミンググラス \\
\hline & $5-3$ & プラズマボール \\
\hline
\end{tabular}

電学論 $A, 127$ 巻 4 号, 2007 年

\section{3. 総合的な学習時間の設計}

〈3.1〉 アンケートによる実態の把握＼cjkstart効果の高い教 育プログラムや学習ユニットは, これまで学習の流れや, 児童たちの意識や知識の定着度合いを踏まえた作成が要に なる。今回総合的な学習の時間でエネルギー教育を実施す る矢巾町立矢巾東小学校では, 2004 年度よりエネルギー教 育に取り組んでいる。児童は, 2004 年度（5 年次）の総合 的な学習の時間で酸性雨について学習している。2005 年度 は，これまでエコクッキングなどを通して，エネルギーの 現状や地球温暖化の原因, 新エネルギーの有効性などを学 び, エネルギーと地球環境について, 調べたり考えたりす る活動を行っている。その中で, 地球規模の環境の悪化や 資源の枯渇を防ぐことの大切さを理解している。これらの 現状を踏まえ, 知識の定着度や知識源, エネルギー環境へ の意識，またどのような取り組みをしているかなどについ てアンケート調査を行った。

児童のエネルギーの知識に関して，アンケートでエネル ギーの種類とそれについて知っていると答えた児童は $97 \%$ であった。また, 環境問題について知っていることについ ては，86\%の児童が地球温暖化と答えている。表 3 に，工 ネルギー資源の自給率に関するアンケート結果の一例を示 す。定量的な把握までには至っていないが，エネルギー資 源のほとんどが輸入であるといった概念は定着しており， エネルギーのスキル学習の効果がうかがえる。また, エネ ルギーの知識の情報源に関するアンケート結果の一例を表 4 に示す。情報源として児童の $78 \%$ は総合的な学習の時間 を，46\%はインターネットをあげている。インターネット はおもに総合的な学習の時間の調べ学習の中で使用してお り, 大半の児童は総合的な学習の時間を通じて知識を得て いることがわかる。

次に, 児童の意識に関して, 地域で行うエネルギー環境 関係のイベントの参加経験や希望に関するアンケート結果 を表 5 に示す。このアンケート結果からわかるように, 児 童は, 地球温暖化の原因や影響などはよく知っているが, 地球環境を守るために地球温暖化を自分自身の問題ととら え，身近な生活の中で，省エネルギーの活動を実践しよう とする態度までは至っていない。これから学びたい環境問 題, 取り組みたい課題は, 「地球温暖化」(35\%), 「リサイ クル・ごみ」 $(27 \%)$,「新エネルギー」 $(21 \%)$ ，「省エネルギ 一の必要性と方法」（10\%）であった。

表 3 知識に関するアンケート結果の一例

Table 3. Typical result of questionnaire for knowledge.

Q.8 現在, 日本全体で使われているエネルギ一資源 (石油·石炭·天然 ガスなど)のうち, 外国からの輸入にたよっている割合は, どのくらいだ と思いますか?（1つ選択）

\begin{tabular}{|r|r||r|c|}
\hline ほぼ $100 \%$ & 3人(8\%) & ほぼ $80 \%$ & 22 人(59\%) \\
\hline ほぼ $60 \%$ & 10 人(27\%) & ほぼ $40 \%$ & 1人(3\%) \\
\hline ほぼ $20 \%$ & 1 人(3\%) & ほぼ $0 \%$ & 0人(0\%) \\
\hline
\end{tabular}


表 4 情報源に関するアンケート結果の一例

Table 4. Typical result of questionnaire for sources of knowledge.

Q.2 エネルギーと, 環境の問題について何から知ったり学んだりしまし たか?(3つまで選択）［上位6位までを記載］

\begin{tabular}{|c|c||c|c|}
\hline $\begin{array}{c}\text { 総合的な } \\
\text { 学習 }\end{array}$ & $\begin{array}{c}29 人 \\
(78 \%)\end{array}$ & インターネット & $\begin{array}{c}17 人 \\
(46 \%)\end{array}$ \\
\hline 理科の授業 & $16 人(43 \%)$ & テレビ·ラジオ & 10 人 $(27 \%)$ \\
\hline 新聞 & 7 人(19\%) & 本·雑誌 & 3 人 $(8 \%)$ \\
\hline
\end{tabular}

表 5 地域活動の参加に関するアンケート結果

Table 5. Result of questionnaire for motivation and activity for a regional community event.

Q.5 地域で実施されるエネルギーや環境イベントへの参加

\begin{tabular}{|c|c|c|}
\hline 活動内容 & $\begin{array}{l}\text { 参加したこと } \\
\text { がある }\end{array}$ & 参加したい \\
\hline $\begin{array}{l}\text { 1. エネルギーや環境につい } \\
\text { てのイベント·講演会 }\end{array}$ & $\begin{array}{l}\text { O人 } \\
(0 \%)\end{array}$ & 21人 (57\%) \\
\hline $\begin{array}{l}\text { 2. 公園や道路, 川などの清 } \\
\text { 掃·美化活動 }\end{array}$ & $\begin{array}{l}26 人 \\
(70 \%)\end{array}$ & $\begin{array}{l}6 人 \\
(16 \%)\end{array}$ \\
\hline $\begin{array}{l}\text { 3. 資源ごみの収集など, リサ } \\
\text { イクル·省資源活動 }\end{array}$ & $\begin{array}{l}0 \text { O人 } \\
(0 \%)\end{array}$ & $\begin{array}{l}\text { O人 } \\
(0 \%)\end{array}$ \\
\hline 4. 省エネルギーの取り組み & $\begin{array}{l}\text { O人 } \\
(0 \%)\end{array}$ & 21人(57\%) \\
\hline $\begin{array}{l}\text { 5. エネルギーや環境に関す } \\
\text { る施設の見学会 }\end{array}$ & $\begin{array}{l}1 \text { 1人 } \\
(3 \%)\end{array}$ & 29人 (78\%) \\
\hline $\begin{array}{l}\text { 6. 実験教室·エ作教室, エコ } \\
\text { クラブなど体験学習会 }\end{array}$ & $\begin{array}{l}2 人 \\
(5 \%)\end{array}$ & 32 人 $(86 \%)$ \\
\hline $\begin{array}{l}\text { 7. 自分の住んでいる地域の } \\
\text { 環境調査 }\end{array}$ & $\begin{array}{l}2 人 \\
(5 \%)\end{array}$ & 19人(51\%) \\
\hline 8. その他 & ○人(0\%) & ○人(0\%) \\
\hline
\end{tabular}

アンケートの結果の解析より，今回の総合的学習の時間 では以下のことを目的とした。（1）エネルギーを大切にす ることについて関心を持って調べたり実験したりしようと する (関心・意欲・態度), （2）省エネルギーの必要性と 方法について理解する,（３）新エネルギーの開発の重要性 やしくみについて理解する (知識・理解)，（4）目的に沿 って, 実験をしたり, 必要な情報を収集したりする（技能・ 表現)，（5）省エネルギーについて調べたり，調查・実験 したりする活動を通して，自分なりの考えを持つ（思考 ・ 判断）。すなわち，今までの学習を生かし，自分たちにでき る省エネを実行でき, 開発が進められている新エネルギー に対しての興味や関心を持ち，新技術を身近なものに感じ てもらうことを目的とした。

$\langle 3 \cdot 2\rangle$ 学習単元の設計 表 6 に, 総合的な学習の時 間の学習計画を示す。前節の目的を実現するように，ゲス トティーチャーの講演を題材にした問題提起からはじめ, 調べ学習や省エネ実践活動で, 環境に最も大切な “できる ことから実践”といった気持ちを持たせるよう試みた。次 に，調べ学習の成果の発表会を行い，お互いの考えを理解
表 6 エネルギー環境学習の設計

Table 6. Design of learning program for energy and environment education.

\begin{tabular}{|c|c|c|c|}
\hline $\begin{array}{l}\text { 項 } \\
\text { 目 }\end{array}$ & 時 & 小単元 & 主な学習内容 \\
\hline \multirow{2}{*}{$\begin{array}{l}\text { 課 } \\
\text { 題 } \\
\text { 把 } \\
\text { 握 }\end{array}$} & $\begin{array}{l}1 \\
\dot{5}\end{array}$ & \multirow[b]{2}{*}{$\begin{array}{l}\text { (1)エネルギーと } \\
\text { 地球環境に } \\
\text { ついて知ろ } \\
\text { う. }\end{array}$} & $\begin{array}{l}\text { ゲストティーチャーから「エネルギ } \\
\text { 一と環境について」の講演を聞き, } \\
\text { エネルギー問題をとらえる. }\end{array}$ \\
\hline & $\begin{array}{l}3 \\
4\end{array}$ & & $\begin{array}{l}\text { 講演会の感想をもとに, エネルギ } \\
\text { 一を大切にするためには, どんな } \\
\text { 取り組みがあるか, 話し合う. } \\
\text { 話し合いをもとに, 自分が実際に } \\
\text { やってみたり, 調べてみたりするこ } \\
\text { とを決める. }\end{array}$ \\
\hline \multirow{2}{*}{$\begin{array}{l}\text { 課 } \\
\text { 題 } \\
\text { 追 } \\
\text { 究 }\end{array}$} & $\begin{array}{l}5 \\
\sim \\
8\end{array}$ & $\begin{array}{l}\text { (2)自分たちに } \\
\text { できる「エネ } \\
\text { ルギーを大 } \\
\text { 切にするな } \\
\text { 法」を調べよ } \\
\text { う. }\end{array}$ & $\begin{array}{l}\text { 「ぼく・わたしの省エネ大作戦」の } \\
\text { 方法を調べる. } \\
\text { エコワットで実際に計測体験し, 結 } \\
\text { 果をまとめる. } \\
\text { インターネットや図書館の資料を活 } \\
\text { 用して調べる. }\end{array}$ \\
\hline & $\begin{array}{c}9 \\
\sim \\
11\end{array}$ & $\begin{array}{l}\text { (3)自分たちが } \\
\text { できる取り組 } \\
\text { みについて, } \\
\text { 調査·実践結 } \\
\text { 果をまとめよ } \\
\text { う. }\end{array}$ & $\begin{array}{l}\text { グループごとに「誰に, 何を, どん } \\
\text { な方法でPRするのか」考え, まと } \\
\text { め方をエ夫する. }\end{array}$ \\
\hline \multirow{3}{*}{$\begin{array}{l}\text { ま } \\
\text { ๖ }\end{array}$} & 12 & $\begin{array}{l}\text { (4)省エネPR大 } \\
\text { 会(発表会)を } \\
\text { しよj. }\end{array}$ & $\begin{array}{l}\text { 発表を聞いて, 自分でもできる省エ } \\
\text { ネについて考える. 発表のエ夫に } \\
\text { ついて考える. }\end{array}$ \\
\hline & $\begin{array}{l}13 \\
\cdot \\
14\end{array}$ & $\begin{array}{l}\text { (5)エネルギーを } \\
\text { 作ろう. (本時 } \\
60 \text { 分) }\end{array}$ & $\begin{array}{l}\text { 省エネと同様, エネルギーの開発 } \\
\text { はなくてはならな重要課題であ } \\
\text { ることを知り, 実際に発電の体験を } \\
\text { する. }\end{array}$ \\
\hline & 15 & 単元のまとめ & 学習したことを振り返る. \\
\hline
\end{tabular}

し，自分の考えを述べられるようにした。最後に，新エネ ルギーなどのエネルギー体験学習を通して, 新しい技術を 身近なものに感じ，エネルギー環境に取り組む気持ちを育 むように，設計した。

表 7 に, 児童へのエネルギー・環境の学習方法へのアン ケート結果を示す。調べ学習や体験学習, 専門家の話に対 する希望が多いことがわかる。すべて実施に地域社会との 連携が必要な内容になっている。地域連携を, 児童の学習 目標の実現に効果的に利用するように，学習のはじめに岩 手県葛巻村役場のバイオマスや風力発電の取り組みについ て，県の職員の方からお話いただくようにした。13，14 回 目には，新しい技術への関心を持ってもらうように，岩手 大学からエネルギー関係に詳しい先生や学生により, 燃料 電池など新エネルギーや既存の発電技術に対する体験型学 習を行うこととした。結果として, 学習方式の時間配分は 表 7 のパーセンテージに近い形となっている。

〈3·3〉学習ユニットの設計 表 8 に, 13，14 時目に あたる学習ユニットを示す。本時は〈3・1〉節で述べた学習 目標の（1），（3），（4）の3 項目に対応している。また, 表 7 の学習方法では, 「実験や体験学習」,「専門家の話」に 対応している。実施に至る前に, 打合せを数回にわたり綿 密に行って, 使用する実験器具や, 班分け, 進め方などを 
打合せ，それぞれ小学校や大学で準備を進めた。教材とし て用いたものは，おおよそ表 2 のリストに示されたもので ある。

体験学習では少人数に分かれた班作業が望ましい。一ク ラスの最大览童数は 40 名であるので，これを 8 班に分け， 実施することとした。班員の最大数は 5 名となる。体験学 習を行う際に, 班の数だけ教材が必要になる。班の数だけ 同じ教材を準備する方法と異なる教材を準備する方法があ る。前者は，同時に同じ学習を行うため対応するスタッフ が少なくて済む利点があり, 後者はいろんな体験をでき, 多くの実験を土台とした広い概念を構築できる利点があ る。今回は, 学習効果を高めるため, 後者を選択した。8つ の教材群を使い，授業時間の中で行えるように，2つのグル ープに分け，図 4 に示すように，2つのコースを作った。児

表 7 学習方法に関するアンケート結果

Table 7. Result of questionnaire for learning method.

Q.4 学校の授業でこれから学習する方法(エネルギーと環境で)

\begin{tabular}{|c|c||c|c|}
\hline 調べ学習 & $\begin{array}{c}30 \text { 人 } \\
(81 \%)\end{array}$ & $\begin{array}{c}\text { 実験や体験学 } \\
\text { 習 }\end{array}$ & $\begin{array}{c}25 人 \\
(68 \%)\end{array}$ \\
\hline 専門家の話 & $\begin{array}{c}13 \text { 人 } \\
(35 \%)\end{array}$ & $\begin{array}{c}\text { 先生の話中心 } \\
\text { の学習 }\end{array}$ & $\begin{array}{c}4 \text { 人 } \\
(11 \%)\end{array}$ \\
\hline 討論·話し合い & $\begin{array}{c}2 \text { 人 } \\
(5 \%)\end{array}$ & $\begin{array}{c}\text { アンケートやイ } \\
\text { ンタビュー }\end{array}$ & $\begin{array}{c}0 \text { 人 } \\
(0 \%)\end{array}$ \\
\hline
\end{tabular}

表 8 新エネルギー体験学習ユニットの設計

Table 8. Design of learning unit for energy education focusing on soft-pass energy.

\begin{tabular}{|c|c|c|c|}
\hline & 学習活動 & 教師の支援と評価 (糸) & 教材 \\
\hline 課 & 1. 本時 の & 新エネルギーは，まだ広く & \multirow{6}{*}{$\begin{array}{l}\text { 児童の新聞 } \\
\text { （地球温暖化） }\end{array}$} \\
\hline 題 & 学習課題を & 普及するまでには至ってい & \\
\hline 把 & 把握する. & ないが, これからの生活を & \\
\hline 握 & & 支える大切な役割があるこ & \\
\hline 5 & & とを確認する.（担任） & \\
\hline 分 & \multicolumn{2}{|c|}{$\begin{array}{l}\text { ○エネルギーを大切にする方法, エネルギ } \\
\text { 一を作り出す方法について知る. }\end{array}$} & \\
\hline \multirow{6}{*}{$\begin{array}{l}\text { 課 } \\
\text { 題 } \\
\text { 追 }\end{array}$} & \multirow{10}{*}{$\begin{array}{l}\text { 2. エネルギ } \\
\text { ーについて } \\
\text { の説明を聞 } \\
\text { く. (10分程 } \\
\text { 度) } \\
\text { 3. 発電の } \\
\text { 体 験をす } \\
\text { る. (35分 } \\
\text { 程度) }\end{array}$} & ゲストティーチャーの説明. & \multirow{10}{*}{$\begin{array}{l}\text { 白 熱灯と蛍 光 } \\
\text { 灯の電力 比較 } \\
\text { 器 } \\
\text { 自転車発電機 } \\
\text { 風力発電 } \\
\text { 太陽光発電 } \\
\text { 燃料電池 } \\
\text { 手回し発電機 } \\
\text { 火力発電模型 } \\
\text { ワンセルカ一 } \\
\text { 燃料電池エ作 } \\
\text { ワークシート }\end{array}$} \\
\hline & & （以下, ゲストティーチャー & \\
\hline & & の指導） & \\
\hline & & $\begin{array}{l}\text { 実物を使った燃料電池の説 } \\
\text { 明 }\end{array}$ & \\
\hline & & & \\
\hline & & 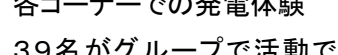 & \\
\hline 求 & & きるよう, それぞれのコーナ & \\
\hline & & 一を数箇所設け, 自由に体 & \\
\hline 45 & & 験できるようにさせる. & \\
\hline & & $\begin{array}{l}\text { ワークシートにしくみを記入 } \\
\text { するようにさせる. } \\
\text { ち体験活動に積極的に参 } \\
\text { 加することができる. }\end{array}$ & \\
\hline ま & 4. 学習感 & •感想を発表させる.（担任） & \multirow{4}{*}{ 感想用紙 } \\
\hline $\begin{array}{l}c \\
\phi\end{array}$ & 発表し, 本 & 论体験学習を通して, 新工 & \\
\hline 10 & & ネルギーの有効性につ & \\
\hline 分 & & いて知ることができる. & \\
\hline
\end{tabular}

童には，班で 1 つ実験をしながら確かめていく簡単なワー クシートを持ち，体験学習をしながら進んでいくこととし た。スタッフが多く必要とするといった問題は, 大学の学 生ボランティアを募り, 6 人の学生に手伝ってもらうことで 回避した。

\section{4. 総合的な学習の実施}

前述の学習ユニットは, 2005 年 11 月 10 日（木）に矢巾 町立矢巾東小学校（校長：高鷹賢司先生）の総合的な学習 時間を使って実施した。対象児童は 6 年 39 名である。エネ ルギーについての説明は, 約 15 分で水の電気分解などのデ モ実験を行いながら, 説明した。その後, クラスを 8 班に 分けて, 電気を作るコースと然料電池のコースに分けて, 実験や工作を行った。いろんな体験学習をスムーズに行え るように, 図 4 に示すテーマ番号に対応した実験机を準備 し，そこにゲストティーチャーやエネルギー教育ボランテ イアの岩手大学の学生（工学部電気電子工学科 4 年生 6 名） を配した。体験学習の際の対応は, 大学からの出張スタッ フが一切を行い, 小学校の先生方も児童といっしょに体験 でき，驚きや感動を共有できるようにした。

総合的な学習の様子の一例を図 5 に示す。体験学習のテ ーマ 2 で自転車発電機を回して, ラジカセや CD を鳴らして いる様子である。日頃, 何気なく使用している家電も, 自

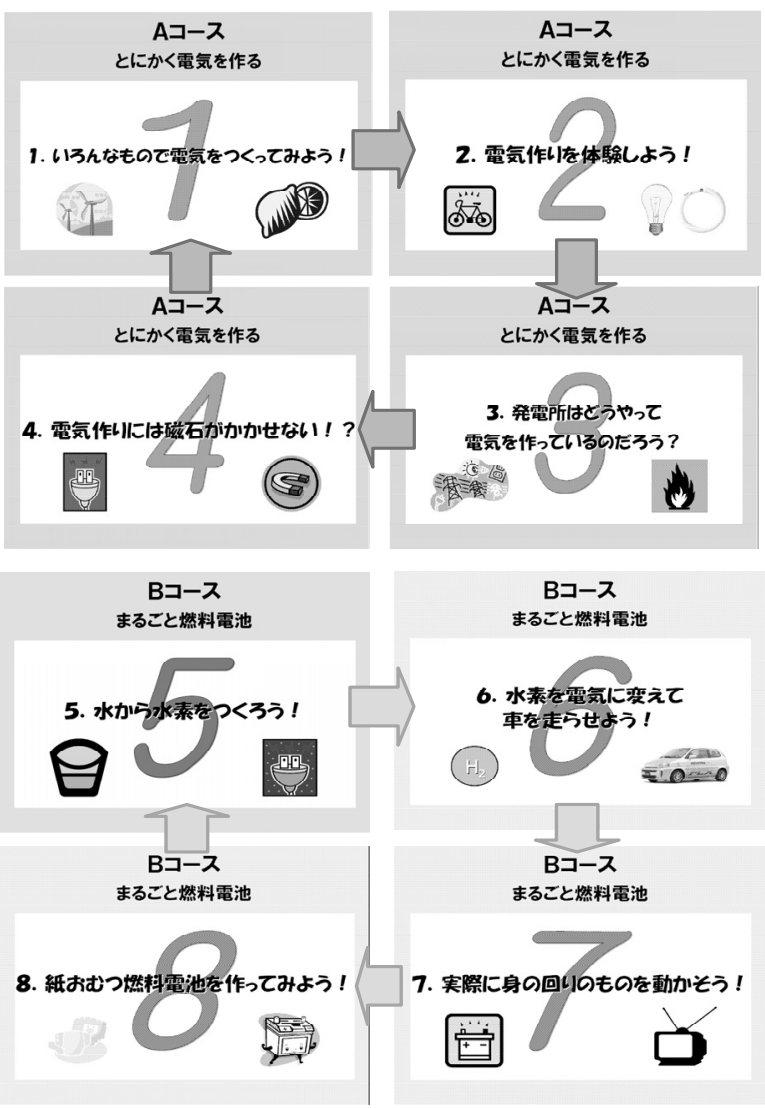

図 4 エネルギー体験学習の 2 つのコース

Fig. 4. Two different courses of experience learning for energy education. 


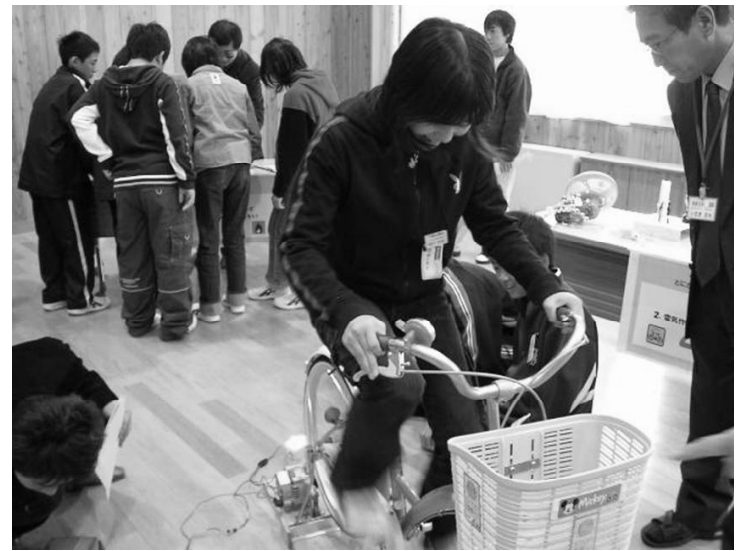

図 5 総合的な学習の時間の様子

Fig. 5. Photograph of the time of synthetic learning.

分で電気を作って鳴らそうとすると，たいへんなことが実 感できる。遠方には他の班が写っている。これはテーマ 3 で火力発電所のモデル実験を見入っている児童である。体 験学習の時間の後は, 表 8 に従って, まとめやわかったこ との発表を通して，理解を深めるようにした。

\section{5. アンケートによる評価}

総合的な学習の時間の終了後, アンケートを通じで児童 の反応を調べた。その結果の一例として，授業前後での省 エネに対する取り組みのアンケート結果を図 6 に示す。図 より, すべての省エネ活動に対して授業前の調査結果に対 して，授業後の方が取り組んでいる人が増えていることが わかる。この結果より，授業の狙いの 1 つである，“地球の 環境を守るために行動ができるようにする”の一部は達成 されていることがわかる。

また，得た知識に対するアンケートの結果として，「エネ ルギーは減ったり増えたりしない。形が変わるだけ」とい った意味の記載も多く見られた。これは知識として浸透さ せるよう学生と打ち合わせておいたもので, 前段階での十 分な打合せや，説明の統制をとることが，児童の習熟度を 上げるために重要なことを示している。今回の授業では, エネルギー変換で生じる損失は取り上げなかった。次のス テップとしては，児童の反応を確認しながら，気づき学習 などで損失を取り上げる展開などを検討する必要がある。

また, 感想としては「いろんなものから電気ができるこ とを知った」や「新しい方法で電気を作ることができない か試してみたい」など, 新エネルギーを題材にしたことで, 電気を中心としたエネルギーを身近に感じている児童も多 く見受けられた。また, 特に自転車発電機の体験を通して 「電気を作るたいへんさを知った」や，さらに「省エネの大 切さを知った」といった感想も見られ，〈3・1〉節で述べた 学習目標の（1），（3），（4）に対しては, かなり有効で あることがわかる。加えて，目的の（2）や（5）も，電 気作りのたいへんさを実感することで，考えを深める効果 もでていることも，アンケートの結果からわかった。

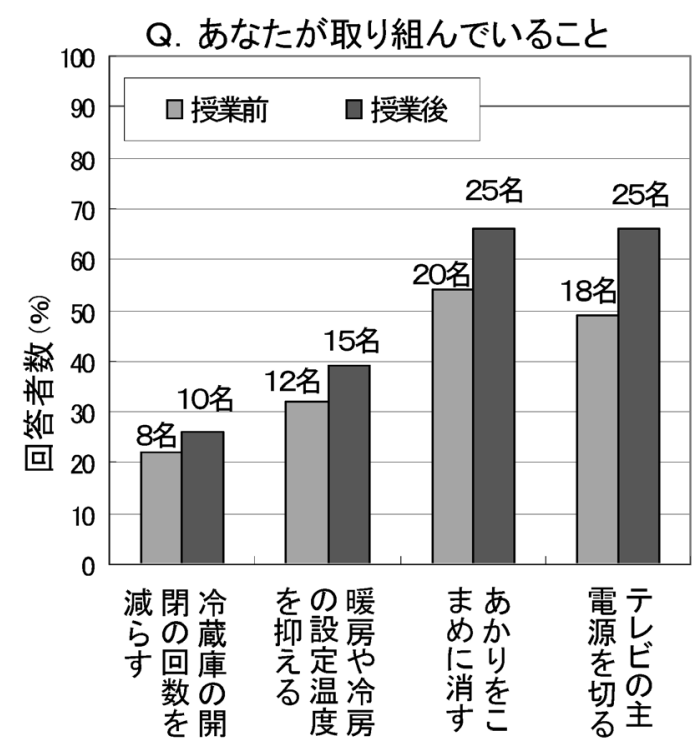

図 6 授業前後での省エネに対する取り組みの変化

Fig. 6. Comparison on activity for environmental action between before and after the course for energy education.

\section{6. まとめ}

小中高校から大学にいたるエネルギー環境の一貫した教 育プログラムの開発と, それを実施するための地域社会の 連携体制の確立や教材開発を目的に，小学校 6 年の児童を 対象にした学習ユニットの開発とそのための教材開発を行 った。開発した教材は, 理科教室などを通じ, 授業で使用 できるように改良を加えた。それらの教材と, 開発した学 習ユニットを利用して, 小学校で総合的な学習の時間を用 いて体験学習を実施した。実施後に行ったアンケートの結 果より, 目的としていた, エネルギ一の理解や省エネを実 践する気持ちを育むなどはおおよそ実現できていることが わかった。また, 県のエネルギー環境関連の機関や大学と 小学校などの地域連携を利用して, 小学校だけでの実施が 困難な体験学習も実施できることが確認された。

最後に, 本研究を進めるにあたり, 静岡大の熊野善介先 生, 高知工科大の八田章光先生, 葛巻町役場の下天广浩様, 矢巾東小学校の高鷹賢司校長先生には貴重なご意見をいた だきました。この場をお借りして，謝意を表します。また， 今回の総合的な学習の時間の実施に際しまして, 矢巾東小 学校の先生方, いわてエネルギー環境教育ネットワーク会 員のみなさま, 岩手大学の地域連携推進センターのみなさ ま, 県の環境生活部の方々, 環境保健センターの方々には 多大なご協力をいただきました。深く感謝いたします。

本研究の一部は, 経済産業省資源エネルギー庁ネルギー 教育調査普及事業『岩手の特質を活かした地域連携型エネ ルギー環境教育プログラムの策定とその実践』, 岩手大学活 性化経費萌芽的教育研究支援『地域連携型エネルギー環境 教育プログラムの策定とその実践』, 北東北国立 3 大学連携 推進研究プロジェクト『北東北エネルギー環境教育ネット 
ワーク構築と教育の実践』の援助を受け行った。

(平成 17 年 6 月 21 日受付, 平成 18 年 1 月 17 日再受付)

\section{文献}

(1) http://www.esd-j.org/whatsesd

（2）文部科学省：小学校学習指導要領, 国立印刷局 (2004)

（3）文部省：環境教育指導資料 (小学校編), 大蔵省印刷局 (1999)

（4）文部省：環境教育指導資料 (中学校・高等学校編), 大蔵省印刷局 (1999)

（5）熊野善介・久田隆基・丹沢哲郎: 「静岡エネルギー環境教育研究会に おける産・官・学連携を基盤とした教師教育について」, 日本教科教 育学誌, Vol.26, No.3, pp.79-82 (2003)

(6) http:// ineee.iwate-u.ac.jp/

（7）（財）社会経済生産本部エネルギー環境情報センター：エネルギー 環境教育推進のための大学におけるエネルギー環境教育の実態調 查，社会経済生産本部エネルギー環境情報センター (2005)

(8) http://www.mext.go.jp/a_menu/koutou/kaikaku/needs.htm

(9) http://chizai.iwate-u.ac.jp/torikumi.html

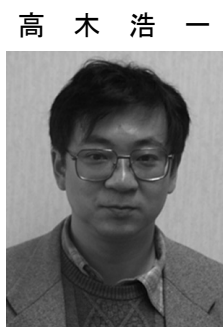

（正員） 1988 年 3 月熊本大学大学院修士課程 修了。1989 年 4 月大分高専電気工学科助手, 1996 年 4 月岩手大学工学部電気電子工学科助 手，2001 年 3 月同助教授，現在に至る。2000 年 10 月～2001 年 9 月マクマスター大学客員研 究員。工学博士。現在の研究テーマは高電圧パ ルスパワー応用や放電プラズマ理工学関係, エ ネルギー環境教育など。エネルギー環境教育学 会, 応用物理学会, 静電気学会, プラズマ・核融合学会, 放電学会, IEEE 会員。

甚 野 伸 雄 (非会員) 2004 年 3 月宮城工業高等専門学校電

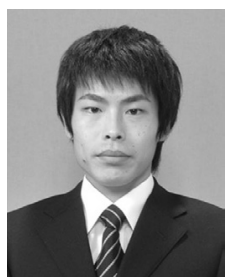
気工学科卒業, 同年 4 月岩手大学工学部電気電 子工学科編入, 2006 年 3 月同校卒業。在学時は, エネルギー環境教育関係の教材開発に従事。同 年 4 月三菱電機（株）入社，現在に至る。

梶 原昌 五 (非会員) 1989 年 3 月東北大学大学院理学研究

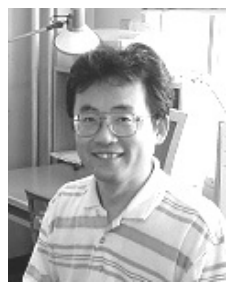
科生物学専攻博士課程後期単位取得退学。1989 年 4 月岩手大学教育学部理科生物学教室助手, 1993 年 10 月同講師, 現在に至る。理学修士。 現在の研究テーマはホヤの神経系, 自然環境教 育など。地域では NPO 法人環境パートナーシ ップいわての理事を務め, 環境問題解決のため の協働の地盤作りに奔走している。日本動物学 会, 日本比較生理生化学会, 日本環境教育学会会員。

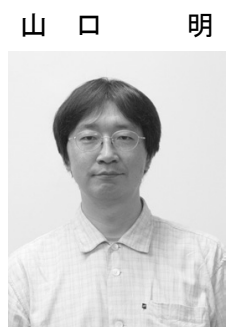

明（非会員）1992 年 3 月東京大学大学院博士課程 修了。1992 年 4 月東京大学生産技術研究所助 手, 1993 年 5 月岩手大学工学部材料物性工学科 講師, 2000 年 4 月岩手大学地域共同研究センタ 一助教授, 2002 年 10 月岩手大学工学部材料物 性工学科助教授, 現在に至る。博士 (工学)。 現在の研究テーマはセラミックスー金属ナノ コンポジット材料とそれを利用した水素セン サーの開発など。エコマテリアルフォーラム幹事。日本金属学会, 日本MRS 学会会員,

菊 地 雅 彦 (非会員) 1985 年 3 月岩手大学教育学部小学校

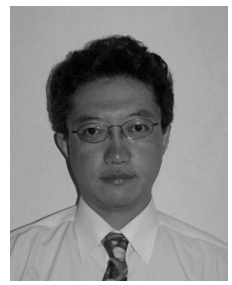
教員養成課程卒業。1985 年 4 月岩泉町立釜津田 小学校教諭, 1986 年 4 月宮古市立津軽石小学校 教諭, 1989 年岩手町立岩瀬張小学校教諭, 1992 年盛岡市立飯岡小学校教諭, 1997 年盛岡市立中 野小学校教諭, 2004 年 4 月矢巾町立矢巾東小学 校教諭, 現在に至る。現在, 矢巾東小学校はエ ネルギー環境教育の実践校として活動してお り, 同校の研究主任を務める。

鈴 木 桃子

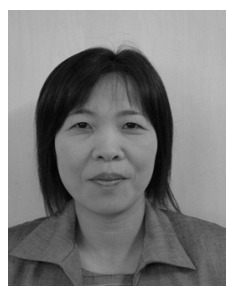

の担任を務める。
（非会員）1985 年 3 月岩手大学教育学部中学校 教員養成課程家政科卒業。1985 年 4 月金ヶ崎町 立二ッ森小学校教諭, 1989 年 4 月江刺市立岩谷 堂小学校教諭, 1992 年 4 月葛巻町立葛巻小学校 教諭, 1997 年 4 月矢巾町立徳田小学校教諭, 2004 年 4 月矢巾町立矢巾東小学校教諭, 現在に 至る。現在, 矢巾東小学校はエネルギー環境教 育の実践校として活動しており, 同校の 6 年生 